\title{
Automobile manufacturers, marketing channels and consumer loyalty
}

\author{
Fabricantes de automóviles, canales de mercadotecnia y \\ lealtad del consumidor
}

\author{
Sara García ${ }^{1}$, Lorena Carrete ${ }^{* 2}$, Pilar Arroyo ${ }^{3}$ \\ EGADE Bussiness School.Instituto Tecnológico y de Estudios Superiores de Monterrey, México
}

Received January 22, 2019; accepted July 23, 2019

Available online August 1, 2019

\begin{abstract}
The aim of this paper is to demonstrate the importance of cooperation between manufacturers of durable goods, specifically cars, and their marketing channels to accomplish strategic goals such as customer retention. A survey was administered to 644 owners of sub-compact cars manufactured by the three lead automakers in Mexico-Nissan, GM and Volkswagen. Based on this data, multi-scales measuring key concepts were validated and a regression analysis applied to test the research hypotheses. Results indicate satisfaction with the car brand and satisfaction with the after-sales services equally contribute to customer loyalty. Meanwhile brand and dealer image directly and indirectly affect loyalty through the mediation of satisfaction. This study adds to the extant literature that recognises the importance of pursuing a joint strategy between manufacturers and retailers to enhance the loyalty of consumers of durable goods. Car manufacturers have an opportunity to increase customer satisfaction and loyalty and consequently their own profitability by being aware of the importance after-sale service has in the intentions of repurchasing the same auto brand.
\end{abstract}

JEL code: M31, M10, M30

Keywords: Marketing channel; After-Sale service; Satisfaction; Loyalty, Dealer image

\footnotetext{
* Corresponding author.

E-mail address: lcarrete@tec.mx (L.Carrete).

E-mail address:Peer Review under the responsibility of Universidad Nacional Autónoma de México.
} 


\section{Resumen}

El propósito de esta investigación es demostrar la importancia de la cooperación entre fabricantes de bienes durables, específicamente carros, y sus canales de mercadotecnia, para alcanzar metas estratégicas tales como la retención de clientes. Una encuesta fue administrada a 644 propietarios de carros subcompactos producidos por las tres armadoras líderes en México- Nissan, GM y Volkswagen. Con base en estos datos, se validaron las multi-escalas desarrolladas para medir los conceptos clave y se aplicó un análisis de regresión para probar las hipótesis de investigación. Los resultados indican que la satisfacción con la marca de carro y con el servicio postventa contribuyen igualmente a la lealtad del consumidor. Mientras que la imagen de la marca y del distribuidor afectan directa e indirectamente a la lealtad a través de la mediación de la satisfacción. Este estudio contribuye a la literatura existente que reconoce la importancia de implementar una estrategia conjunta entre fabricantes y detallistas para fortalecer la lealtad de los clientes de bienes durables. Los fabricantes de automóviles tienen la oportunidad de incrementar la satisfacción y lealtad del consumidor, y consecuentemente su propia rentabilidad, al ser conscientes de la importancia que tiene el servicio postventa en la intención de recomprar la misma marca de auto.

Código JEL: M31, M10, M30

Palabras clave: Canal de mercadotecnia; Servicio postventa; Satisfacción; Lealtad; Imagen del detallista

\section{Introduction}

The economic and environmental challenges, the unprecedented increase in the use of technology and variety of products, and the customer's empowerment, have increased the need to modify the corporate structure and recognize the interdependence between members of the supply chain. To effectively match demand with supply, suppliers, manufacturers, retailers and service support organizations need to collaborate. In the particular case of the automotive industry, automakers have fostered true multi-directional collaboration to offer more differentiated and complex products at competitive prices. The development of collaborative projects with selected suppliers for product co-design and improvement of process and products have been increased. For example, the collaboration between Corning and Sharp has enabled the manufacturing of larger and environmentally friendly LCDs while Honda shares with its supplier what products intends to develop as well as what improvements are necessary to enhance the quality and costs of current products. In the automotive sector, over 
$50 \%$ of the total products components are manufactured by external suppliers. Consequently, supplier-manufacturer collaboration has been an important topic for researchers and practitioners (McClellan, n.d; Oh and Rhee, 2008).

The co-creation of value between automakers and strategic suppliers is a common practice, but the opportunity of attending the industry challenges by collaborating with dealers has not been fully recognized in despite they are the direct contact with end customers and their services are essential to build up a strong brand (PwC network, 2013). The importance of the relationships between manufacturers and their marketing channels has been analysed by authors such as Bloom and Perry (2001) and Amato and Amato (2009) resulting in a change in perspective, from the traditional product-centric view to a more innovative customer-centric view (Saccani, Songini and Gaiardelli, 2006; Gopalani, 2010). By promoting a participative channel environment, adequate empowerment and reward systems, the automaker may strength the relation with the dealers to more effectively market their products, assure the car brand identity is reflected accurately, and after-sales services fulfil the quality standards. In a supplier-dominant channel, as the automaker-dealer case, participative and supportive management styles have been shown to have a positive effect on customer orientation, customer relationship, attraction and retention of customers, and consequently on profitability (Chang, Chen and Polsa, 2003). By 'keeping' customers and managing positive brand associations, retailers contribute to customer satisfaction and loyalty which are ones of the primary resources for building competitive advantage (Gopalani and Shick, 2011).

Although customer loyalty has been scrutinised for many decades, there are clear gaps in the knowledge of the antecedents of loyalty (Lai, Griffin and Babin, 2009) particularly in terms of how the actions of different integrants of the supply chain affect the loyalty of the final customer. According to Kumar, Pozza and Ganesh (2013), more studies, including relevant variables either as antecedents, mediators or moderators of the relationship between satisfaction and loyalty, may improve the explanation and prediction of loyalty. In this work, we intend to enhance the comprehension about what variables influence loyalty by including 'image' as an antecedent of the relationship, and also examine simultaneously how image and satisfaction with automakers and dealers affect customer loyalty. This study focuses on the automotive sector because the importance of this industry to the Mexican economy and because, as stated before, the dealer's role is critical to customer attraction and retention (BBVA Research, 2010; Rial, 2001; Vicencio-Miranda, 2007). For example, the dealer's financial plans or their maintenance and repair services may influence the decision to buy a particular car brand.

The theoretical framework for this article is based on two pillars. The first pillar relates to the conceptualization of satisfaction and loyalty and its study on the automotive context. The second pillar captures the factors that contribute to forming a brand and distributor 
image in the retailing industry. This framework serves as a platform into which the results of our empirical study will be integrated. Subsequent section describes the methodology of the study, including the sample characteristics and techniques for data analysis. Finally, the results of the study are shown and discussed, and avenues for future research are proposed.

\section{Satisfaction and loyalty of automobile customers}

Satisfaction is defined as a cognitive response that results from an evaluative process that contrasts pre-purchase expectations with perceptions of performance during and after the consumption experience (Oliver, 1980). In addition, it has also been conceptualised as an affective state, characterised by emotions and moods that influence behaviour (Westbrook and Oliver, 1991). Regarding loyalty, this concept is described as a deeply held commitment to rebuy or re-patronise a preferred product/service consistently in the future in spite of situational influences that may cause switching behaviour (Oliver, 1999).

Satisfaction is associated with the consumer response to the outcome of the service offered by the seller and the difference between the product's actual and expected performance (Yoo and Park, 2016). In the automotive sector, Bloemer and Lemmink (1992) stated that global satisfaction is composed of satisfaction with the car, satisfaction with the sales service and satisfaction with the after-sale service. Satisfaction with the car is basically associated with the technical characteristics of the product offered by the automaker (Amineh and Kosach, 2016), whereas satisfaction with services is mainly associated with the service (pre- and after-sale) quality delivered by the dealer (Gustafsson and Johnson, 2002; Devaraj, Matta y Conlon, 2001). Using the American Consumer Satisfaction Index (ACSI), Yu, Wu, Chiao and Tai (2005) studied Lexus-Toyota in Taiwan while Terblanche (2006) focused on Toyota and Volkswagen. Both studies concluded that the ACSI model can be applied successfully to the automotive market to predict customer loyalty, with satisfaction mainly expressed in terms of perceived quality of the car. Bei and Chiao (2001) extended this model by testing the effect of perceptions of car attributes, quality and price fairness and the quality of the maintenance service on customer loyalty to the dealers of three brands-Mitsubishi, Nissan and Toyota - using satisfaction as the mediator.

Customers' satisfaction with the sales service has been claimed to be a specific determinant of loyalty by authors such as Roscino and Pollice (2004). Other authors have confirmed that even though satisfaction during the sales stage is important, satisfaction with the after-sale service - the quality of technical service, accessories and parts replaced, the honesty of employees and delivery time of the vehicle-also has a critical influence on loyalty (Mittal et al., 1999). For example, Saccani et al. (2006) analysed the role of after-sales services (A/S) 
in three different manufacturing contexts - automotive, household appliances and consumer electronics - and concluded their role to be particularly relevant in the automotive sector.

The strategic role of $\mathrm{A} / \mathrm{S}$ shifts in favour of a more proactive perspective that considers them an alternative to create sustainable relationships with customers, contribute to further differentiate products and improve competitive advantage (Saccani et al., 2006; Ahn and Sohn, 2009). Hence, excellent A/S may significantly enhance the value of the product to consumers, thereby inducing repurchase from existing customers and attracting new ones (Malik, 2012). The extant literature acknowledges customer satisfaction (with product and/or services) is the basis of loyalty, although the relationship is subject to the influence of different moderator factors and external influences such as the type of industry under analysis (Biscaia, Rosa, Moura e Sá and Sarrico, 2017). Consequently, as noticed in the introduction, considering the effect of other variables is relevant to enhance the comprehension about how loyalty may be constructed. The insertion of variables that indirectly affect loyalty through the mediation of satisfaction, first requires to demonstrate the relationship between satisfaction and loyalty under a specific context. Therefore, we formulate the following two research hypothesis:

H1. Satisfaction with the car brand has a positive influence on consumer loyalty. H2. Satisfaction with the automotive dealer's after-sale service has a positive influence on consumer loyalty.

\section{Brand and retailer image}

Research has demonstrated the importance of both store and brand image for business life, suggesting that image considerations guide purchase choice (He and Lai, 2014). Satisfaction is also considered a result of the customer's evaluation of the tangible and intangible brand attributes (Krystallis and Chrysochou, 2014), accordingly, the extant literature ascertains image indirectly influences loyalty, through satisfaction (He and Lai, 2014; Kim and Lee, 2010; Nesset et al., 2011; Silva and Giraldi, 2010; Yu and Ramanathan, 2012). In general, empirical research concludes image is relevant to loyalty with satisfaction having a greater influence on loyalty than image (Veloso, Magueta, Ribeiro and Alves, 2018).

Keller (1993) proposed the notion that brand image is a multidimensional concept that includes attributes, benefits and attitudes. Attributes are specific or tangible characteristics of the product, such as colour and size, or abstract elements such as personality traits. Benefits refer to the consumers' perceptions of the needs that have been satisfied by the product/brand, whereas attitudes are consumers' overall evaluations of a brand. Aaker (1996) also outlined 
three dimensions or components to image: perceived value, personality and organisation. The first component refers to the relationship between price and quality, the second to the symbolic and emotional traits that distinguish the brand and the third to the company itself and its reputation. In general, the more favourable the image the higher the consumer satisfaction and, consequently, the loyalty (Johnson, Gusstafsson, Andreassen, Lervik and Cha, 2001).

Regarding the retailer or, more generally, the distributor image, the concept has been defined based on the retail store's attributes (Hopkins and Alford, 2001). Lindquist (1974) established nine dimensions of store image that influence consumer perceptions and subsequent behaviours: merchandise, service, clientele, physical facilities, convenience, promotion, store atmosphere, institutional factors and post-transaction satisfaction. Mazursky and Jacoby (1986) empirically tested the multidimensionality of retail image proposed by Lindquist and concluded that the dimensions affecting consumer perceptions were quality of goods (a specific element of merchandise), service quality and atmosphere. Other authors have verified the relevance of location and ease-of-access to the store (specific elements of convenience) and merchandising on satisfaction and, consequently, on consumer loyalty (Kim and Jin, 2001; Koo, 2003; Yoo and Chang, 2005). More recently, Mafini and Dhurup (2015) proved the influence of store appeal and promotional activities on consumer satisfaction. Abrudan, Plaias and Dabija (2015) also proved that store décor, price, service, customer retention policy and communication affect intentional loyalty through the mediation of satisfaction. Translating these findings to the automotive sector with the dealer as retailer, the following hypotheses are stated:

H3. Brand image indirectly influences loyalty towards a car brand via the mediation of satisfaction with the brand.

H4. Dealer image indirectly influences loyalty towards a car brand via the mediation of satisfaction with the A/S of the dealer.

\section{Method}

The methodology comprised two phases: 1) developing and validating the measurement scales for the theoretical constructs of interest and 2) testing the research hypotheses as presented in the model framework (Figure 1). The first phase was necessary due to the limited conceptual clarity of the dealer and brand image in the automotive sector. No studies that operationalised dealer image were identified; therefore, the extant literature in the retail sector was the basis to develop the corresponding scale. Regarding the other constructs, we adopted measures developed previously but validated them in the Mexican context. 
Figure 1 describes graphically the relationships to be empirically validated in this research.

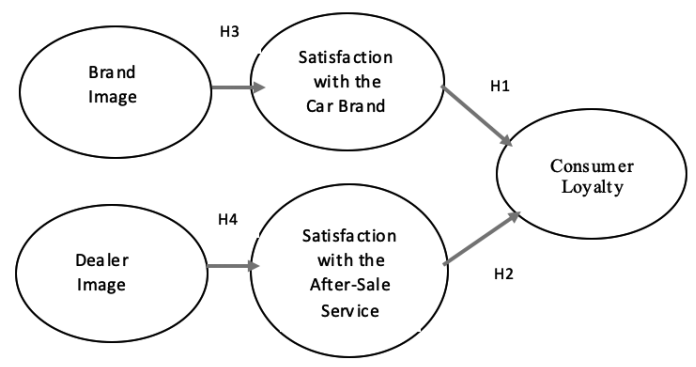

Figure 1. Framework explaining Loyalty in the Automotive Sector

Source: Own elaboration

\section{Development and validation of measurement scales}

Following Malhotra and Grover's (1998) process for developing measurement scales, initial items for the themes of brand image and store image were drawn from the literature review and, then, were discussed with a group of customers in terms of their relevance on the purchase decision. In-depth interviews were conducted with 45 consumers of the three leading car brands in the Mexican market: Nissan, GM and Volkswagen (AMDA, 2018; Vicencio-Miranda, 2007). The participants were customers of car dealers and had purchased a car in the last five years and had experience with the $\mathrm{A} / \mathrm{S}$ of the dealer. After a qualitative analysis of these data (Neuendorf, 2002), 21 items related to image were selected. Five of those assessed the components of brand image, namely, brand personality, lifestyle, brand and corporate reputation, and perceived value expressed as quality versus price paid. The remaining 16 items corresponded to the following dimensions of dealer image: convenience, merchandise, atmosphere, tangibles, service and perceived value. All the image items were represented by a five-point Likert scale $(1=$ strongly agree to $5=$ strongly disagree $)$ with the option 'I do not know' also included.

The two image scales were integrated with a questionnaire, including a seven-item scale assessing satisfaction with the car of a specific brand and a 10-item after-sales satisfaction scale. The satisfaction items were reported on a five-point scale from $1=$ completely satisfied to $5=$ completely dissatisfied while the four loyalty items were expressed on a five-point probability scale to recommend/repurchase the same car brand with the same dealer $(1=\mathrm{I}$ surely will to $5=$ there is no chance I will). The resulting 42 -item instrument was administered to 685 owners of sub-compact cars residents in the metropolitan area of the Valley of 
Toluca, the capital of the State of Mexico. Residents in the two main municipalities of the six enclosed in this area, Toluca and Metepec, were surveyed. This geographical region it is one of the largest car markets in the country (AMDA, 2018).

We establish contact with the main dealers of the three car brands with major participation in the Mexican market: Nissan, GM and Volkswagen. The objectives of the research project were explained to the general managers and after several visits, three dealers, one of each brand, finally accepted to cooperate by providing access to their customer's databases. In exchange, they received a technical report of the results of the study, only the part corresponding to their customers was submitted to each dealer. A stratified random sample of consumers with equivalent allocation (same sample size in each stratum) of the three car brands, was selected from the three car dealers' databases. Selected consumers were contacted via telephone and those who agreed to participate were interviewed. A total of 644 consumers completed the survey resulting in a $94 \%$ response rate. The participants were mainly males $(63.5 \%)$ and young adults between 20 to 35-years-old (42.3\%), mostly married (53.8\%) with at least a Bachelor's degree $(42.4 \%)$ and with a middle socioeconomic level (63.3\%).

To validate the multi-item scales, first, we performed a reliability analysis consisting of: a) computation of item-to-total correlations to discard items with low internal consistency and b) calculation of Cronbach's coefficient alpha for each of the five theoretical constructs. Four items were eliminated due to their low item-to-total correlation while the alpha coefficients computed with the remaining 38-items ranged from 0.757 (brand image) to 0.886 (dealer image), thus supporting the scale's reliability. Then, an Exploratory Factor Analysis was conducted using principal component analysis (PCA). Eight factors with eigenvalues above 1.0 resulted; however, the eigenvalues of the last two factors barely exceed 1.0 (1.11 and 1.19) while the analysis of the scree-plot suggests a more parsimonious solution with only six factors. Another seven items were deleted due to their low communalities (below 0.35), resulting in a 31-item purified instrument. A varimax rotation to the six-factor solution was applied; this solution explains $60.1 \%$ of the original variance, which is considered satisfactory in social science (Hair, Anderson, Tatham and Black, 2005).

The factor solution exhibited good discrimination among the constructs. With respect to convergent validity, all the items assigned to a particular construct, except for dealer image, loaded onto the same factor when using a benchmark factor loading greater than or equal to 0.45 . Table 1 reports a summary of the results of the EFA.

Regarding dealer image, the 11 items of the multiscale were grouped into two factors, thus, confirming the multidimensionality of this concept (Koo, 2003). The first factor mainly comprised items related to the layout of the auto sales agency: this sub-dimension was named atmosphere and convenience. The second factor included items related to pricing and complimentary services such as restrooms and entertainment: this sub-dimension was named complementary services and pricing. 
Table 1

Exploratory Factor Results

\begin{tabular}{|c|c|c|}
\hline Factor & Items & Loadings \\
\hline \multirow{3}{*}{ Dealer image: } & Appropriate service hours & .660 \\
\hline & Convenience of location & .715 \\
\hline & Appropriate layout & .589 \\
\hline \multirow{4}{*}{$\begin{array}{l}\text { atmosphere and } \\
\text { convenience }\end{array}$} & Appropriate distribution of service areas & .611 \\
\hline & Appropriate visibility and signage of areas and departments & .628 \\
\hline & Availability of a good variety of cars & .547 \\
\hline & Pleasant atmosphere (colour, temperature, odour and background music) & .490 \\
\hline \multirow{4}{*}{$\begin{array}{l}\text { Dealer image: } \\
\text { complimentary } \\
\text { services and } \\
\text { pricing }\end{array}$} & $\begin{array}{l}\text { Sufficient and appropriate services areas (restrooms, showroom and re- } \\
\text { ception) }\end{array}$ & .627 \\
\hline & Sufficient and appropriate entertainment services (TV, videos) & .773 \\
\hline & Appropriateness of reception services (drinks and snacks) & .669 \\
\hline & Perception of fair prices and good financing plans & .450 \\
\hline \multirow{4}{*}{ Brand image } & This car brand reflects my personality & .806 \\
\hline & This car brand has an excellent reputation in the market & .798 \\
\hline & This automaker has an excellent reputation in the market & .459 \\
\hline & The quality of the car corresponds to the price paid for it & .515 \\
\hline \multirow{6}{*}{$\begin{array}{l}\text { Satisfaction with } \\
\text { after-sale service }\end{array}$} & Reception (time, schedule and appointment) of the unit & 608 \\
\hline & Friendliness of the employees & .581 \\
\hline & Quality of the technical services & .774 \\
\hline & Quality of accessories and parts & .703 \\
\hline & Delivery time of services & 699 \\
\hline & Cost of after sales services & .684 \\
\hline \multirow{6}{*}{$\begin{array}{l}\text { Satisfaction with } \\
\text { the car (brand) }\end{array}$} & Satisfaction with the general quality of the particular car brand & .693 \\
\hline & Comfort of the car & .706 \\
\hline & Manoeuvrability of the car & .723 \\
\hline & Technical performance of the purchased car & .668 \\
\hline & Safety of the car & .654 \\
\hline & Car price & .574 \\
\hline \multirow{3}{*}{ Loyalty } & Intention to repurchase the same car brand & .743 \\
\hline & Willingness to recommend the car brand & .781 \\
\hline & Intention to repurchase with the same dealer & .825 \\
\hline (intended) & Willingness to recommend the dealer & .749 \\
\hline
\end{tabular}




\section{Results and Discussion}

\section{Testing of the research model}

To get empirical support to the first two research hypotheses, loyalty was explained in terms of the following independent variables: 1$)$ satisfaction with the car brand, $\mathrm{b}_{1}$ (standardised) $=$ $0.328, t(641)=9.03, P$-value $=0.000$, and 2$)$ satisfaction with the after-sales services provided by the dealer $\mathrm{b}_{2}($ standardised $)=0.326, t(641)=8.98, P$-value $=0.000$. These two variables explained a significant proportion of the variance in the loyalty intentions: $R^{2}=33 \%, F(2$, $641)=156, P$-value $=0.000$. The value of the standardised regression coefficient is almost the same, thus indicating satisfaction with the car is equally significant to loyalty as satisfaction with the A/S. Although the importance of satisfaction with the quality of the physical product as well as the after-sales service to assure consumer loyalty has been recognized long time ago (Bloemer and Lemmink, 1992), recent research addressing simultaneously the influence of satisfaction with durable goods and with the retailer's service on loyalty was not identified. In the automotive sector, Matzler et al. (2004) evaluate only the attributes of the product and demonstrate that the quality of products is a key driver of satisfaction. Meanwhile Saccani et al. (2006) and Borchardt, Souza, Pereira and Viegas (2018) evaluated the relevance of A/S satisfaction of car costumers. Thus, the present empirical research is opportune to support the notion that product attributes as well as after-sales service are critical aspects for consumers of durable goods such as cars.

To test for the mediating effect of satisfaction stated by hypotheses 3 and 4, we applied the standard approach of estimating three regression equations using ordinary least squares (Shaver, 2005). First, we regressed loyalty on (brand or dealer) image and, then, the image was regressed on the proposed mediator (satisfaction). Finally, we assessed whether image still affects loyalty when controlling for satisfaction. Table 2 summarises the results of this procedure: the number in parenthesis in front of each estimated regression coefficient stands for the $P$-value of the $t$-statistic used to test the null hypothesis that the partial/marginal regression coefficient is zero.

The regression coefficients of the models reported in Table 2 that include brand and dealer image are statistically significant thus concluding brand and dealer image play an important role in determining customer satisfaction (Regression 2) and loyalty (Regression 1) as put forward by previous studies (Suh and Yi, 2006; Veloso et al., 2018). The results obtained also indicate each dimension of dealer image has a different effect on satisfaction as observed by other authors such as Silva and Giraldi (2010) who in the case of a shoe store conclude service and convenience is the most influential retailer image dimension. 
S. García, et al. / Contaduría y Administración 65(3) 2020, 1-17

http://dx.doi.org/10.22201/fca.24488410e.2020.2411

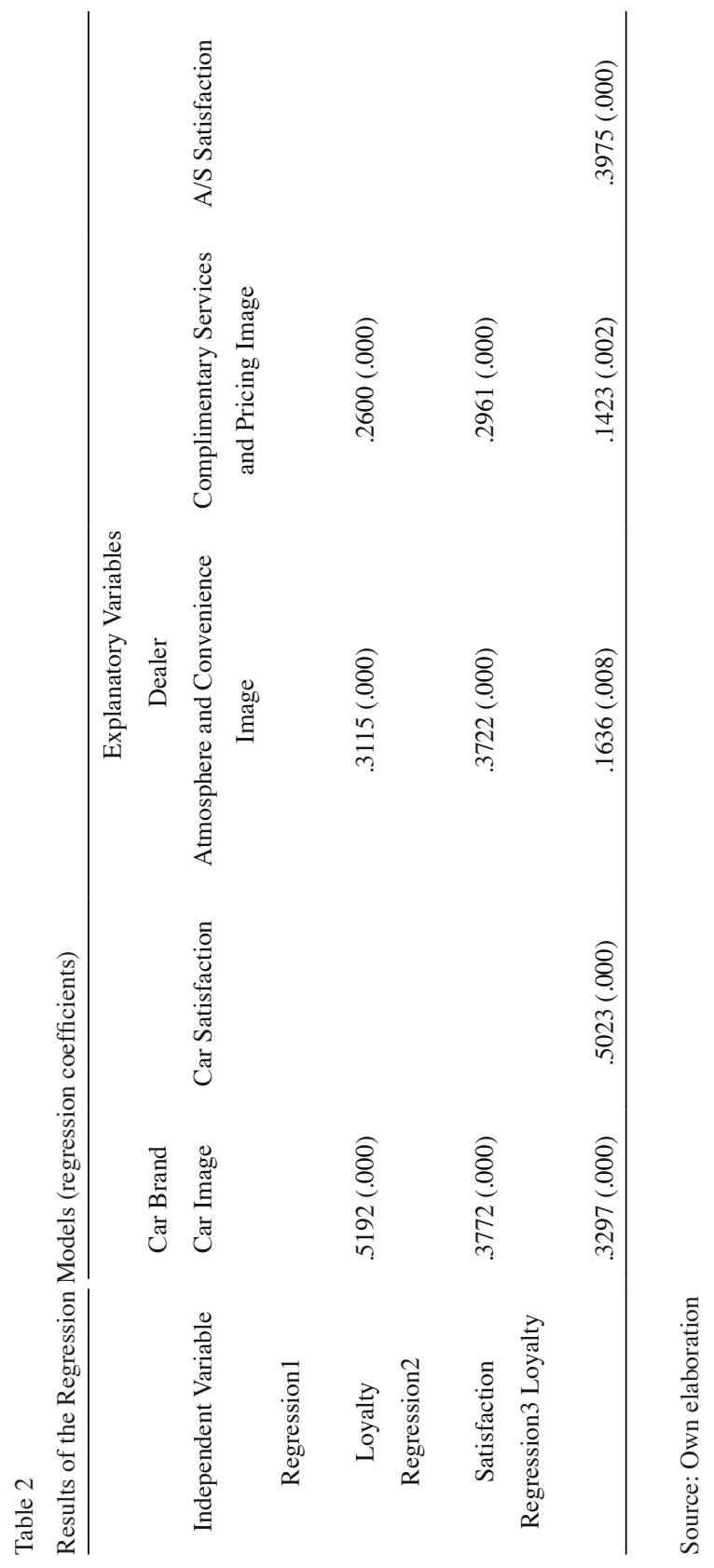


The regression coefficients of (car or dealer) image in the regression models (Regression 3) that also include the mediating variable satisfaction, are considerably smaller than the coefficients of the regression models that only include image as an explanatory variable: 0.5192 versus 0.3297 in the case of brand image; 0.3115 versus 0.1636 in the case of the atmosphere and convenience with the dealer's facilities (first dealer image sub-dimension); and .2600 versus .1423 for the complimentary services and pricing offered by the dealer (second dealer image sub-dimension). Then we conclude that satisfaction partially mediates the relationship between image and loyalty as stated in Hypotheses 3 and 4. This implies that brand and dealer's image influence loyalty directly and indirectly thus confirming image across the marketing channel is important to drive the preferences of the consumer. The direct effect of retailer image on loyalty has been confirmed by authors such as Veloso et al. (2018), who conclude Portuguese customers, experiencing a good service, form a favourable image of traditional retailer stores that directly influences loyalty. But in contrast with Veloso and co-authors, who did not identify a direct influence of image on customer satisfaction, the present study concludes dealer image has both a direct and indirect effect on loyalty via the mediation of A/S satisfaction. This finding confirms customer satisfaction is not the single direct antecedent of loyalty, being relevant to ponder the influence of other antecedents such as image (Nyadzayo and Khajehzadeh, 2016).

In their study of durable goods, González-Hernández, Orozco-Gómez and Barrios (2011) conclude the level of involvement of the purchase determines how brand attitude and brand experience influences attitudinal loyalty. While tangible brand attributes influence the attitude towards the brand independently of the level of involvement, intangible attributes result more influential in the case of high involvement purchases. Thus, depending on the kind of products, distinct components of brand image need to be highlighted. The findings of our research suggest that in the case of automobiles, that involve a high involvement purchase, the quality of the product and the price paid for it (brand tangibles) as well as the car brand and automaker reputation (brand intangibles), should be promoted to increase satisfaction and loyalty with the brand. While regarding dealer image, convenience of location, financial plans, entertainment and service areas, a pleasant atmosphere and availability of a good variety of cars (dealer image's tangibles) will contribute to enhance satisfaction with the dealer.

Recently, Meinzer et al. (2016) propose how to improve the measurement of customer satisfaction in the segment of a premium car manufacturer by using as benchmark the health care services. The empirical results of their study show the service encounter is a critical determinant of satisfaction with the dealer and willingness to recommend it, followed by situational factors and sociodemographics. Given the great importance of the A/S service, these authors propose car manufacturers should closely monitor the service quality and image of dealers and include satisfaction with dealer's services as one of the components of ove- 
rall customer's satisfaction. These recommendations agree with the advice of Gopalani and Shick (2011) that automakers and dealers cooperate to assure consumers the availability of auto-parts and the quality of the repair and maintenance services required by the car during its life cycle to increase customer satisfaction and loyalty.

\section{Conclusions}

The importance of inter-organisational relationships to accomplish strategic goals such as customer retention is recognised in this study. Mostly, the academic literature related to the automotive industry has focused on the collaborative relations among automakers and their strategic suppliers with the goal of improving product performance and advancing technological innovation. Meanwhile the study of the cooperation of automakers with dealers, who are the direct contact with final customers and responsible of the product's functionality after the sale, has not received the same attention. This research contributes to the limited academic research that analyses how the construction and communication of a consistent good image for both dealer and automaker, and the satisfaction of customer's requirements regarding product performance and maintenance and repair services, contributes to loyalty. Brand and corporate reputation as well as dealer image's tangibles improve the explanation and prediction of loyalty directly and through the mediation of satisfaction with car performance and the dealer's service.

An ancillary academic contribution of this study is the development and validation of ad hoc metrics to measure image of car brand and dealer, and multi-scales that distinguish between car and dealer A/S satisfaction. The proposed measures confirm the applicability of store image scales to the automotive context. Aspects such as service hours, store location, product availability and product placement in the retail area, all relevant aspects regarding image of supermarkets and department stores (Bloemer and Ödekerken-Schröeder, 2002; Koo, 2003), also resulted significant in the automotive sector. Two main components comprising the dealer image are specifically identified: the atmosphere and convenience of the dealer's facilities and their pricing strategy and complimentary services. Given the sensitivity to prices of Mexican consumers of compact and sub-compact cars, the establishment of a joint pricing strategy becomes relevant to guarantee profitability for car manufacturers and dealers and improve the dealer's image. As regards to satisfaction, previous studies such as the one performed by Bloemer and Lemmink (1992), for example, did not specify the metrics used for satisfaction with the after-sale dealer services or satisfaction with the car, while Huber and Herrmann (2001) only focus on satisfaction with dealers' sales service. In contrast, the metrics proposed in this study clearly differentiate between satisfaction with the car brand and with $\mathrm{A} / \mathrm{S}$ services. 
A first extension of this study is directly related to its limitations. The data were collected only in the metropolitan area of the Toluca Valley which limits the generalizability of results. Replications of the study in other metropolitan areas of Mexico and Latino American countries with contrasting socioeconomic conditions will be relevant to confirm the findings. To reduce a potential sample bias in these replication studies, dealers should be randomly selected among those most interested in satisfying their customers; efforts to persuade selected dealers to participate in future studies are required. Secondly, we focus on the major segment of automobiles, that is sub-compact car's consumers. Forthcoming studies of niche car segments will be relevant, first to verify if the same dimensions of both, brand image and dealer image, influence loyalty through satisfaction, and secondly to include new variables that may affect loyalty. Particularly, two niche segments are interesting, the luxury cars which provide a higher revenue to automakers and the segment of hybrid cars which is growing given the current environmentally friendly trend. In the case of luxury cars, in addition to brand image, social identity is a variable that may influence satisfaction. Meanwhile for the hybrid cars segment, environmental values and conspicuous consumption may moderate the relation between satisfaction and loyalty.

Finally, loyalty of consumers of durable goods may be assessed by taking into consideration all of its components, namely affective, cognitive, conative and behavioral dimensions (Oliver, 1999). Similarly, additional dimensions of brand and dealer image should be taken into account, such as the processes of payment of financial credits and insurance claims, the availability of advanced driver assistance technologies and innovative connectivity services. It is clear that loyalty will remain a topic of study because of the difficulty that most organizations face in retaining their customers and the increased awareness of the dealer's role on customer relationship management.

\section{References}

Aaker, D. A. (1996). Measuring brand equity across products and markets. California Management Review, 38 (3), 102-120. https://doi.org/10.2307/41165845

Abrudan, I.-N., Plăiaș, I. \& Dabija, D. C. (2015). The relationship among image, satisfaction and loyalty - innovative factor of competitiveness for shopping centers. Amfiteatru Economic, 17 (39), 536-552.

Ahn, J. S. \& Sohn, S. Y. (2009). Customer pattern search for after-sales service in manufacturing. Expert Systems with Applications, 36, 5371-5375. https://doi.org/10.1016/j.eswa.2008.06.061

Amato, L.H.\& Amato, Ch. H. (2009). Changing retail power and performance in distribution channels. International Journal of Retail \& Distribution Management, 37 (12), 1057-1076. https://doi.org/10.1108/09590550911005029 AMDA (2018). Estadísticas de la Asociación Mexicana de Distribuidores de Automotores. Available at: http:// www.amda.com.mx.

Amineh, H. \& Kosach, N. (2016). Assessment of Consumers' Satisfaction with the Automotive Product Quality. International Journal of Environmental \& Science Education, 11 (16), 8726-8739. 
BBVA Research (2010). Latinoamérica Situación Automotriz. Available at: http://www.bbvaresearch.com/KETD/ fbin/mult/ESTAULT_14122010_tcm346-239499.pdf?ts=2662012.

Bei, L. T. \& Chiao, Y. C. (2001). An integrated model for the effects of perceived product, perceived service quality. Journal of Consumer Satisfaction, Dissatisfaction and Complaining Behavior, 16 (3/4), 125-140.

Biscaia, A. R., Rosa, M. J., Moura e Sá, P. \& Sarrico, C. S. (2017). Assessing customer satisfaction and loyalty in the retail sector. The International Journal of Quality and Reliability Management, 34 (9), 1508-1529. https:// doi.org/10.1108/IJQRM-03-2015-0039

Bloemer, J. \& Lemmink, J. (1992). The importance of customer satisfaction in explaining brand and dealer loyalty. Journal of Marketing Management, 8 (4), 351-364. https://doi.org/10.1080/0267257X.1992.9964204

Bloemer, J. \& Ödekerken-Schröeder, G. (2002). Store Satisfaction and Store Loyalty Explained by Customer and Store Related Factors. Journal of Consumer Satisfaction, Dissatisfaction and Complaining Behavior, 15 (January), 68-82.

Bloom, P. N. \& Perry, V. G. (2001). Retailer power and supplier welfare: The case of Wal-Mart. Journal of Retailing, 77, 379-396. https://doi.org/10.1016/S0022-4359(01)00048-3.

Borchardt, M., Souza, M., Pereira, G. \& Viegas, C. V. (2018). Achieving better revenue and customers' satisfaction with after-sales services: How do the best branded car dealerships get it? International Journal of Quality \& Reliability Management, 35 (9), 1686-1708. https://doi.org/10.1108/IJQRM-01-2017-0016

Chang, T. Z., Chen, S. J. \& Polsa, P. (2003). Manufacturer channel management behavior and retailers' performance: an empirical investigation of automotive channel. Supply Chain Management: An International Journal, 8 (2), 132 -139. http://dx.doi.org/10.1108/13598540310468733

Devaraj, S. K., Matta, K. F. \& Conlon, E. (2001). Product and service quality, antecedents of customer loyalty in the automotive industry. Production and Operations Management, 10 (4), 424-439. https://doi.org/10.1111/j.1937-5956.2001.tb00085.x

González-Hernández, E. M., Orozco-Gómez, M. M. \& Barrios, A. P. (2011). El valor de la marca desde la perspectiva del consumidor. Estudio empírico sobre preferencia, lealtad y experiencia de marca en procesos de alto y bajo involucramiento de compra. Contaduría y Administración, 235 (septiembre-diciembre), 217-239.

Gopalani, A. (2010). A new model for service businesses in product $\square$ centric firms. Journal of Business Strategy, 31 (6), 4-11. https://doi.org/10.1108/02756661011089026

Gopalani, A. \& Shick, K. (2011). The service-enabled customer experience: a jump-start to competitive advantage. Journal of Business Strategy, 32 (3), 4-12. https://doi.org/10.1108/02756661111121947

Gustafsson, A. \& Johnson, M. D. (2002). Measuring and managing the satisfaction-loyalty-performance links at Volvo. Journal of Targeting, Measurement and Analysis for Marketing, 10 (3), 249-258. https://doi.org/10.1057/ palgrave.jt.5740050

Hair Jr., J. F., Anderson, R. E., Tatham, R.L. \& Black, W. C. (2005). Análisis Multivariante, México: Pearson Prentice Hall.

He, Y. \& Lai, K. K. (2014). The effect of corporate social responsibility on brand loyalty: the mediating role of brand image. Total Quality Management \& Business Excellence, 25 (3/4), 249-263. https://doi.org/10.1080/1 4783363.2012.661138

Hopkins, C. D. \& Alford, B. L. (2001). A new seven-dimensional approach to measuring the retail image construct. Academy of Marketing Studies Journal, 5 (2), 105-114.

Johnson, M.D., Gustafsson, A., Andreassen, T.W., Lervik, L. \& Cha, J. (2001). The evolution and future of national customer satisfaction index models. Journal of Economic Psychology, 22, 217-245. https://doi.org/10.1016/ S0167-4870(01)00030-7

Huber, F. \& Herrmann, A. (2001). Achieving Brand and Dealer Loyalty: The Case of the Automotive Industry. The International Review of Retail, and Consumer Research, 11 (April), 97-122.https://doi.org/10.1080/713770584

Keller, K.L. (1993). Conceptualizing, measuring, and managing customer-based brand equity. Journal of Marketing, 57 (January), 1-22. https://doi.org/10.1177/002224299305700101 
Kim,J.\& Jin,B.(2001). Korean consumers' patronage of discount stores: domestic vs. multinational discount store shoppers' profiles. Journal of Consumer Marketing, 18 (3), 236-255. https://doi.org/10.1108/07363760110393092.

Kim, Y. E. \& Lee, J. W. (2010). Relationship between corporate image and customer loyalty in mobile communications service markets. African Journal of Business Management, 4 (13), 4035-4041.

Koo, D. (2003). Inter-relationships among store image, store satisfaction, and store loyalty. Asia Pacific Journal of Marketing and Logistics, 15 (4), 42-71. https://doi.org/10.1108/13555850310765033.

Krystallis, A. \& Chrysochou, P. (2014). The effects of service brand dimensions on brand loyalty. Journal of Retailing Consumer Services, 21 (2), 139-147. https://doi.org/10.1016/j.jretconser.2013.07.009

Kumar, V., Dalla Pozza, I. \& Ganesh, J. (2013). Revisiting the satisfaction-loyalty relationship: empirical generalizations and directions for future research. Journal of Retailing, 89 (3), 246-262. https://doi.org/10.1016/j. jretai.2013.02.001

Lai, F., Griffin, M. \& Babin, B. J. (2009). How quality, value, image, and satisfaction create loyalty at a Chinese telecom. Journal of Business Research, 62, 980-986. https://doi.org/10.1016/j.jbusres.2008.10.015

Lindquist, J. D. (1974). Meaning of image- a survey of empirical and hypothetical evidence. Journal of Retailing, 50 (4), 29-38.

Mafini, C. \& Dhurup, M. (2015). Drivers of customer loyalty in South African retail stores. The Journal of Applied Business Research, 31 (4), 1295-1310. https://doi.org/10.19030/jabr.v31i4.9317.

Malhotra, M.K. \& Grover, V. (1998). An assessment of survey research in POM: from constructs to theory. Journal of Operations Management, 16 (17), 407-25. https://doi.org/10.1016/S0272-6963(98)00021-7.

Malik, S. U. (2012). Customer satisfaction, perceived service quality and mediating role of perceived value. International Journal of Marketing Studies, 4 (1), 68-76. https://doi.org/10.5539/ijms.v4n1p68

Matzler, K., Bailomb, F., Hinterhuber, H., Renzl, B. \& Pichler, J. (2004). The asymmetric relationship between attribute-level performance and overall customer satisfaction: a reconsideration of the importance-performance analysis. Industrial Marketing Management, 33, 271-277. https://doi.org/10.1016/S0019-8501(03)00055-5

Mazursky, D. \& Jacoby, J. (1986). Exploring the development of store images. Journal of Retailing, 62 (2), 145165.

McClellan, M. (n. d.). Automotive Industry Collaboration. Vancouver, CA: Collaborative Manufacturing Whitepaper Series. Available at: http://www.cosyninc.com/pdf/Auto.pdf.

Meinzer, S., Prenninger, J., Vesel, P., Kornhuber, J., Volmer, J., Hornegger, J. \& Eskofier, B. (2016). Translating satisfaction determination from health care to the automotive industry. Service Business, 10 (4), 651-685. https:// doi.org/10.1007/s11628-015-0284-z

Mittal, V., Pankaj K. \& Tsiros, M. (1999). Attribute-level performance, satisfaction and behavioral intentions over time: a consumption system approach. Journal of Marketing, 63 (2), 88-101. https://doi. org/10.1177/002224299906300206, https://doi.org/10.2307/1251947

Nesset, E., Nervik, B. \& Helgesen, O. (2011). Satisfaction and image as mediators of store loyalty drivers in grocery retailing. The International Review of Retail, Distribution and Consumer Research, 21 (3), 267-292. https://doi.org/10.1080/09593969.2011.588716

Neuendorf, K. A. (2002). The Content Analysis, United States: SAGE Publications.

Nyadzayo, M. W. \& Khajehzadeh, S. (2016). The antecedents of customer loyalty: A moderated mediation model of customer relationship management quality and brand image. Journal of Retailing and Consumer Services, 30, 262-270. https://doi.org/10.1016/j.jretconser.2016.02.002

Oh, J. \& Rhee, S. K. (2008). The influence of supplier capabilities and technology uncertainty on manufacturer-supplier collaboration. A study of the Korean automotive industry. International Journal of Operations and Production Management, 28 (6), 490-517. https://doi.org/10.1108/01443570810875331

Oliver, R.L. (1980). A cognitive model of the antecedents and consequences of satisfaction decisions. Journal of Marketing Research, 17, 460-469. https://doi.org/10.1177/002224378001700405, https://doi.org/10.2307/3150499

Oliver, R. L. (1999). Whence consumer loyalty? Journal of Marketing, 63, 33-44. https://doi.org/10.1177/00222429990634s105. 
PwC Network (2013). Looking ahead. Driving co-creation in the auto industry. Available at: https://www.pwc. com/gx/en/automotive/industry-publications-and-thought-leadership/assets/pwc-looking-ahead-driving-cocreation-in-the-auto-industry-pdf.pdf.

Rial, A. J. (2001). Análisis de Competitividad del Sector Automotriz Argentino. Documento de Trabajo $N^{\circ}$ 64, Universidad de Belgrano. Available at: http://www.ub.edu.ar/investigaciones/dt_nuevos/64_rial.pdf

Roscino, A. \& Pollice, A. (2004). A statistical analysis of the customer satisfaction with car dealers. Applied Stochastic Models in Business and Industry, 20 (3), 281-289. https://doi.org/10.1002/asmb.520

Saccani, N., Songini, L. \& Gaiardelli, P. (2006). The role and performance measurement of after-sales in the durable consumer goods industries: An empirical study. International Journal of Productivity and Performance Management, 55 (3/4), 259-283. https://doi.org/10.1108/17410400610653228

Shaver, J. M. (2005). Testing for mediating variables in management research: concerns, implications, and alternative strategies. Journal of Management, 31 (3), 330-353. https://doi.org/10.1177/0149206304272149.

Silva, T. S. \& Giraldi, J. M. E. (2010). The influence of store image on customer satisfaction: a case study of a shoe store. Brazilian Business Review, 7 (2), 60-77. https://doi.org/10.15728/bbr.2010.7.2.4.

Terblanche, N. S. (2006). An application of the American customer index (ACSI) in the South African Motor Vehicle Industry. South African Journal of Business Management, 37 (4), 29-38. https://doi.org/10.4102/sajbm. v37i4.611

Veloso, C. M., Magueta, D., Ribeiro, H. \& Alves, S. R. (2018). The links between service quality, brand image, customer satisfaction and loyalty in the retail industry. 28th International Scientific Conference on Economic and Social Development. Paris, 19-20 April 2018, 497-511.

Vicencio-Miranda, A. (2007). La industria automotriz en México. Antecedentes, situación actual y perspectivas. Contaduría y Administración, 221 (enero-abril), 211-248.

Westbrook, R.A. \& Oliver, R.L. (1991). The Dimensionality of Consumption Emotion Patterns and Consumer Satisfaction. Journal of Consumer Research, 18 (1), 84-91. https://doi.org/10.1086/209243

Wong, C. Y. \& Johansen, J. (2008). A framework of manufacturer $\square$ retailer coordination process: three case studies. International Journal of Retail \& Distribution Management, 36 (5), 387-408. https://doi. org/10.1108/09590550810870111

Yoo, S. J. \& Chang, Y. J. (2005). An exploratory research on the store image attributes affecting in store loyalty. Seoul Journal of Business, 11 (1), 20-41.

Yoo, J. \& Park, M. (2016). The effects of e-mass customization on consumer perceived value, satisfaction, and loyalty toward luxury brands. Journal of Business Research, 69 (12), 5775-5784. https://doi.org/10.1016/j. jbusres.2016.04.174

Yu, C.J., Wu, L., Chiao, Y. \& Tai, H. (2005). Perceived quality, customer satisfaction and customer Loyalty: The Case of Lexus in Taiwan. Total Quality Management, 16 (6), 707-719. https://doi.org/10.1080/14783360500077393

Yu, W. \& Ramanathan, R. (2012). Retail service quality, corporate image and behavioral intentions: the mediating effects of customer satisfaction. The International Review of Retail, Distribution and Consumer, 22 (5), 485505. https://doi.org/10.1080/09593969.2012.711250. 